\title{
Analysis and Environmental Assessment of Biomass and Biofuels Usage Possibilities in Cogeneration Cycle
}

\author{
Vytautas Kučinskas, Algirdas Jasinskas ${ }^{1}$, Eglë Jotautienė \\ Institute of Agricultural Engineering and Safety, Faculty of Agricultural Engineering, \\ Aleksandras Stulginskis University, Studentu str. 15, Akademija, LT-53362 Kaunas reg., Lithuania \\ 1 algirdas.jasinskas@asu.lt
}

\begin{abstract}
There is presented technical-technological analysis of decentralised energy production in cogeneration cycle using plant biomass and biofuels. It was determined that in perspective in Lithuania power of power plants heated by biofuel shall reach 10-15 MW. Having evaluated the amount of growth of oily cultures in Lithuania, possibilities to use vegetable oil and its blends with mineral diesel in cogeneration power plants were proven. Distribution of energy flows in $1050 \mathrm{~kW}$ cogeneration power plant with diesel engine was presented. It was defined that mechanical power of the engine is twice smaller than the obtained heat power of the module. Having performed the environmental evaluation of biofuels, it was determined that the least emission of $\mathrm{CO}$ and solid particles to the environment was got using rapeseed oil fuels. However, during its burning bigger amount of $\mathrm{NO}_{x}$ gets into the air if compared to mineral diesel or rapeseed ester methyl. Tasks requiring scientific research were formulated. These tasks shall optimise the possibility to use biofuels in cogeneration power plants using internal combustion engines. There is presented technical-economical assessment of cogeneration power plants using rapeseed oil for fuel.
\end{abstract}

Keywords: Biomass, Biofuels, Cogeneration power plants, Mineral diesel, Rapeseed oil, Fuel blends, Oilseeds.

(C) Copyright 2014 Authors - This is an Open Access article published under the Creative Commons Attribution License terms (http://creativecommons.org/licenses/by/3.0). Unrestricted use, distribution, and reproduction in any medium are permitted, provided the original work is properly cited.

\section{Introduction}

Cogeneration is one of the key measures to reduce the prime-cost of electricity production using existing technologies. Considering energetic value of the used energy as 100\%, during cogeneration cycle we receive $45 \%$ of electrical energy and $40-45 \%$ of thermal energy, and loss of energy production makes only $10-15 \%$ [1]. The main condition for effective operation is stable demand for thermal energy. Electrical energy is a by-product of the technological process. In Europe, in the long run this technology has been little widespread in the energy market. In 1998, the installed capacity of this type of power plants accounted for about $70 \mathrm{GW}$, and only in the recent years the average power of the plant has exceeded the limit of $10 \mathrm{MW}$. Meanwhile, in the Eastern Europe, with a large part of the centrally prepared and supplied thermal energy, cogeneration power plants make a considerably larger share of energy balance. Cogeneration energy generated by the energy market is increased in two ways: construction of commercial energy facilities for production of heat or cold; construction of micro-generational objects ("household power system"). The target was to produce about 20\% of electric energy in cogeneration power plants in 2013. This fact became the basis for the European Commission (EC) to issue a directive promoting construction of cogeneration power plants and legal basis supporting application of this technology [2].

Electricity generation in cogeneration mode is an effective way to reduce environmental pollution, economical use of non-renewable and expand use of renewable energy resources. The European Union has a large potential to expand the use of this technology. Taking into account different level of economic development and specifics of industry and its conditions, the European Commission granted Member States freedom in decision making.

In the recent years, a particular focus is placed on usage of biomass, biofuels and alternative fuels in cogeneration cycle and efficiency increase $[3,4,5,6]$. In the European Union, the biggest part of boiler plants heated by biomass is made by boiler plants of small and medium power with the nominal power from 10 to $150 \mathrm{MW}$. In such systems, heat needs in 
summer and transitional period are only 3-15 MW. In cogeneration regime in such boiler plants it is possible to install electric generators with the power from several hundred to several megawatts. As it is proven by the performed analysis, cogeneration energy objects are economically effective only if they annually operate not less than 7-8 thousand hours [6]. Another precondition to carry out this project is sufficient amount of biomass for fuel production in the region, its offer and price. Strong competition is characteristic to the market of wooden waste. The market is composed of producers of wooden fibre and sawdust, cellulose and paper producers, private sector and recently appeared in the market wooden briquettes and granules producers. Less competition is found in the market of wood waste and especially for biomass grown plants. Transportation distance for correctly chosen biomass suppliers should not exceed $50 \mathrm{~km}$.

Presently, some main electricity generation technologies are applied. First is a steam boiler with steam turbine. Chopped wood, straw and energetic plants may be used for fuel production. In boilers of smaller power (5-10 MW), it is hard to reach high parameters of technological steam $\left(400-600^{\circ} \mathrm{C}\right.$ temperature and $700-800 \mathrm{~km} / \mathrm{h}$ steam supply to the turbine speed). Coefficient of efficiency of the system (if generating electricity up to $1 \mathrm{MW}$ of the installed power) makes $10-15 \%$. Condensate heat exchanger in burning product channels may partly improve coefficient of efficiency. The accumulated in biomass energy may be fully used by producing heat energy. Used in condensate heat exchanger steam heats hot water. In this way, $60-70 \%$ of the primary energy is used purposefully $[5 ; 6]$.

A system using a steam piston engine with closed working heat cycle instead of a turbine is characterised by higher technological parameters. The engine works without pulling of working cylinder surfaces. Depending on technological steam parameters, one and two/three extension cycle engines are produced. Engines are of a simple construction and are easy to maintain. Range of power is wide enough - from 100 to $1000 \mathrm{~kW}$ in one block, and steam demand is up to $40 \mathrm{t} / \mathrm{h}$. The main advantage of a steam engine if compared to a steam turbine is a possibility to work in loads' range from 20 to $100 \%$ with constant energy generation coefficient of efficiency higher than $50 \%$. In energetic power blocks up to $1 \mathrm{MW}$, a steam engine guarantees $2-5 \%$ higher coefficient of efficiency than steam turbine.

Recently, energetic blocks working on ORC (Organic Rankine Cycle) cycle was appeared and started to be exploited [7; 8]. Differently from a common watersteam cycle, organic liquid (isooctane, toluene, silicon oils) is used for heat transition in operating frame. Temperature of a heat-transfer agent $\left(310^{\circ} \mathrm{C}\right)$ is not high. The system operates in the closed cycle. Differently from water-steam turbines, ORC cycle is characterised by a turbine of smaller rotation, and small load of mechanic turbine. Apart from that, operating surfaces of the blades are safe from erosion, complicated water preparation technology is not needed, and coefficient of efficiency is higher with the higher load of the aggregate. In this power plant, waste of heat and electricity make only $3-5 \%$, and coefficient of efficiency of electricity production is 0.18 . The remaining part of energy is used for heat production in cogeneration regime.

Despite their simplicity, all the mentioned schemes are hardly fully automated and cannot operate fully autonomously. ORC cycle power plants are in the initial launching stage and are related to high investment costs. To this end, usage of stationary internal combustion engines has more advantages. Their construction is quite perfect, and it is adopted by the producers. Cogeneration energetic power modules up to $10 \mathrm{MW}$ are produced. Power costs of the installed power plant are from 580 to 1620 EUR/kWe. Another important characteristic of internal combustion engines is quick launch and reach of the maximal power and high elasticity in wide range of powers. Either liquid or gas fuel may be used for production of fuels. Modern blocks may be managed distantly and operate in the regime of constant generation and autogeneration. Table 1 presents comparison of energetic efficiency for cogeneration power plants with the power up to 10 MW using biomass $[7 ; 8 ; 9 ; 10]$. 
Table 1. Indices of energetic efficiency of cogeneration technologies $[7 ; 8 ; 9 ; 10]$

\begin{tabular}{|c|c|c|c|c|c|c|}
\hline \multirow{2}{*}{ Parameters } & \multicolumn{5}{|c|}{ Variants of cogeneration power plants } \\
\cline { 2 - 6 } & \multicolumn{3}{|c|}{ Low-power } & \multicolumn{2}{c|}{$\begin{array}{c}\text { Low-power with mass } \\
\text { gasification }\end{array}$} \\
\cline { 2 - 7 } & $\begin{array}{c}\text { Closed- } \\
\text { cycle } \\
\text { steam } \\
\text { turbine }\end{array}$ & $\begin{array}{c}\text { Gas } \\
\text { turbine }\end{array}$ & $\begin{array}{c}\text { ORC cycle } \\
\text { turbine }\end{array}$ & $\begin{array}{c}\text { Gas Otto } \\
\text { engine }\end{array}$ & $\begin{array}{c}\text { Gas } \\
\text { turbine } \\
\text { turbine } \\
\text { with STIG } \\
\text { cycle }\end{array}$ \\
\hline $\begin{array}{c}\text { 1. Coefficient of efficiency } \eta_{\mathrm{el}} \\
\text { of electricity production in } \\
\text { cogeneration regime, \% }\end{array}$ & 17.0 & 11.0 & 15.0 & 27.0 & 24.6 & 37.4 \\
\hline $\begin{array}{c}\text { 2. Coefficient of efficiency } \eta_{\mathrm{el}} \\
\text { of heat production in } \\
\text { cogeneration regime, \% }\end{array}$ & 68.0 & 74.0 & 70.0 & 56.0 & 59.0 & 27.2 \\
\hline $\begin{array}{c}\text { 3. Annual coefficient of } \\
\text { energetic efficiency } \eta_{\mathrm{e}} \%\end{array}$ & 85.0 & 85.0 & 85.0 & 83.0 & 84.6 & 84.6 \\
\hline $\begin{array}{c}\text { 4. Annual index of } \\
\text { cogeneneration } \mathrm{k}_{\mathrm{r}}\end{array}$ & 0.25 & 0.15 & 0.21 & 0.48 & 0.43 & 1.4 \\
\hline $\begin{array}{c}\text { 5. Relative economy of the } \\
\text { initial energy, \% }\end{array}$ & 27.1 & 21.4 & 25.3 & 25.3 & 33.0 & 31.0 \\
\hline
\end{tabular}

Having evaluated the provided data in view of energetic efficiency, variants of power plants shall be arranged as follows: gas Otto engine, gas turbine, gas turbine with STIG cycle, steam turbine, ORC cycle turbine, steam engine. If burning biomass directly, coefficient of efficiency of generation of electric energy makes approx. $20 \%$. If biomass is burned in a power plant with integrated biomass gasification, coefficient of efficiency is up to 38\% [11]. However, launching of such technology is stopped by high investment costs. Technological process is rather complicated and takes place at high temperature $\left(700-1200^{\circ} \mathrm{C}\right)$. Depending on quality of the initial raw materials, caloricity of the obtained gas blend is from 3 to $7 \mathrm{MJ} / \mathrm{m}^{3}$, and it is not high.

Biogas obtained in bioreactors during splitting of biomass by microorganisms in non-oxygen environment may be used as fuel. The obtained gas blend is composed of methane (40-80\%), carbon (20$55 \%)$ and hydrogen sulphide (0.1-5.5\%) [12; 13]. Various raw materials may be used for production of biogas. Apart from plant mass, one may use litter, waste products of food industry and forage, silt of waste waters, waste of public utilities and wood processing.

Differently from usual power plants, in cogeneration power plant additional heat exchangers are installed. These heat exchangers enable to get heat from biogas compressor, systems of engine cooling and lubrication and channel of the exhaust. Part of heating (approx. $15 \%$ ) and electric (7.5\%) energy is used for internal technological needs, such as maintenance of bioreactor's temperature regime, preparation of biomass, cleaning and conditioning of biomass, and sorting of waste. Biogas that is formed in dumps and purifiers can also be used for internal combustion engines. Recently corn has become a perspective plant biomass used for production of biogas in reactors. $700 \mathrm{~m}^{3}$ of biogas may be obtained from one ton of dry organic mass that contains approx. $50 \%$ of methane. Prime cost of biogas is 0.12 $0.13 \mathrm{EUR} / \mathrm{m}^{3}$, and the price of the cleaned and prepared for burning gas (bio-methane) is 0.26-0.32 $\mathrm{EUR} / \mathrm{m}^{3}$. Corn plantation of 150 ha (if crop capacity is not less than $50 \mathrm{t} / \mathrm{ha}$ ) enable you to get about 1.5 million cubic meters of gas. This quantity is sufficient for operation of cogeneration module $370 \mathrm{~kW}$ electric and $440 \mathrm{~kW}$ heat power of 8000 hours per year [13].

From the technological point of view, the easiest realised variant is usage of vegetable oils and biofuels in cogeneration power plants. If compared to the above-mentioned variants, changes in engine fuel supply system are minimal: exchange of system sealing elements by the ones resistant to vegetable oils and installation of heating system of the supplied fuels. A big advantage of this variant consists in the fact that without stopping operation of the power plant you may change a sort of the used fuel. This saves from stoppage of the energetic module in case of disorder in biofuel supply.

Vegetable oil and biofuel use in cogeneration cycle in Lithuania also promotes biomass produced in agriculture and resources of products obtained from this biomass. The resources of hydroelectric power 
plants, wind energy are high temperature geothermal resources in Lithuania are minimal. There are no possibilities to use sources of flood energy and high temperature solar energy. In the nearest future, the major part of the produced clean energy shall be made by energy blocks using biomass. Potential of plant biomass utilization for energy purposes is presented in figure $1[14,15]$.

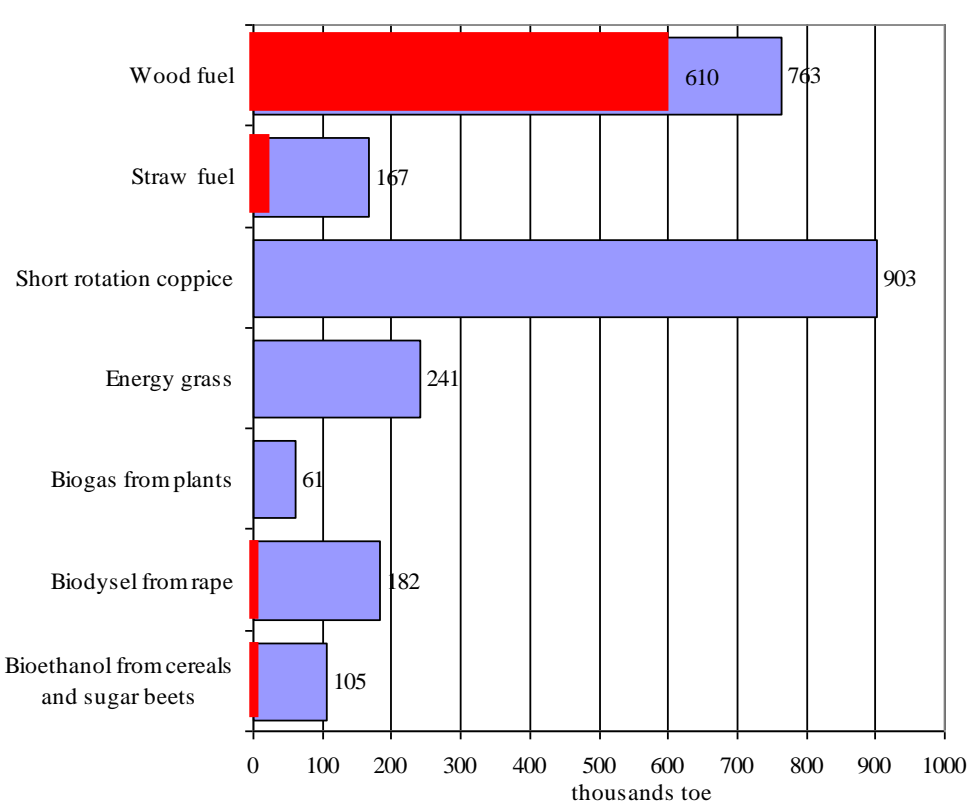

Figure 1. Potential of plant cultivation and use for energy purposes in Lithuania's agriculture (the currently used amounts are presented in block) $[14,15]$
In recent years the interest in usage of vegetable oil for fuel production in some countries of $\mathrm{EU}$ increases [16]. In 2009 in Lithuania were produced 108 thousand tons of biofuels. It is forecasted that this need shall not increase significantly. Aiming to implement the requirement of the EU that until the year 2020 biofuels should make $10 \%$ of the entire quantity of the used fuel, it is projected to produce about 110 thousand tons of biofuels that year. In Lithuania biofuels are usually produced from rapeseeds. It has been determined that rape for production of biofuels shall be grown in the area of 290 thousand ha.

Development of biofuels production is supported not only by higher interest to environment protection and constantly increasing price of mineral fuels, but also desire of people involved in agriculture to depend less on energy market. Using vegetable oil in tractors and cars, a farmer may provide himself with fuels by growing vegetable plants himself and use the cake to feed domestic animals. Based on the performed research results it was determined that the biggest yield of oil is in rapeseed - up to $45 \%$, sunflower seeds - up to $40 \%$, oily radish - up to 35 $\%$, oily linseeds - up to $35 \%$, soya - up to $24 \%$. However, not all oils are suitable for fuels due to their physical-chemical characteristics. Rapeseed oil is the most suitable. Table 2 provides the main characteristics of rapeseed oil, biodiesel and mineral diesel [17].

Table 2. The main characteristics of rapeseed oil, biodiesel and mineral diesel [17]

\begin{tabular}{|c|c|c|c|}
\hline Parameters & Rapeseed oil & Mineral diesel & Biodiesel \\
\hline Density, $\mathrm{g} / \mathrm{cm}^{3}$ & $0.91-0.93$ & $0.82-0.85$ & $0.86-0.90$ \\
\hline $\begin{array}{c}\text { Kinematic quagmire under the } \\
\text { temperature of } 40^{\circ} \mathrm{C}, \mathrm{mm}^{2} / \mathrm{s}\end{array}$ & 38.0 & $2.0-4.5$ & $3.5-5.0$ \\
\hline Cetane number $^{\text {Boundary filter temperature, }{ }^{\circ} \mathrm{C}}$ & $40-42$ & $51-56$ & 50 \\
\hline${\text { Outburst temperature, }{ }^{\circ} \mathrm{C}}_{\text {Sulphur quantity, } \mathrm{mg} / \mathrm{kg}}^{-(9-15)}$ & 220 & -14 & - \\
\hline Calorific value, $\mathrm{MJ} / \mathrm{kg}$ & $<20$ & $50-80$ & $<-135$ \\
\hline
\end{tabular}

As we may see from these data, rapeseed oil (if compared to biodiesel and mineral diesel) is characteristic of the following: its quagmire is much higher, boundary filter temperature is higher, cetane number is lower. Rapeseed oil is non-toxic and is rather fireproof. Differently from mineral oil products, rapeseed oil does not have objectionable odour and taste. This oil does not contain sulphur compounds; so, its burning does not form acid rains, and other dangerous chemical compounds do not get into atmosphere. According to the calculations, the amount of the separated heat received by burning oil and diesel fuel is almost the same. Oil has higher outburst temperature which makes it more attractive for usage in stationary engines installed in enclosed space $[18 ; 19 ; 20]$.

The study of the performed analytical research has revealed that growing tendencies to use diesel engines in cogeneration cycle are associated with possible usage of vegetable oil and its blends. However, there is lack of research evaluating 
environmental and economic advantages of such systems.

The aim of research was to analyse impact of vegetable oil usage in cogeneration cycle on the environment and its economic benefits.

\section{Materials and methods}

Studies were conducted in the Lithuanian Institute of Agricultural Engineering. While determining energetic and emission rates of vegetable oil usage for fuel, laboratory tests were carried out. Laboratory bench measurements are presented in figure 2 .

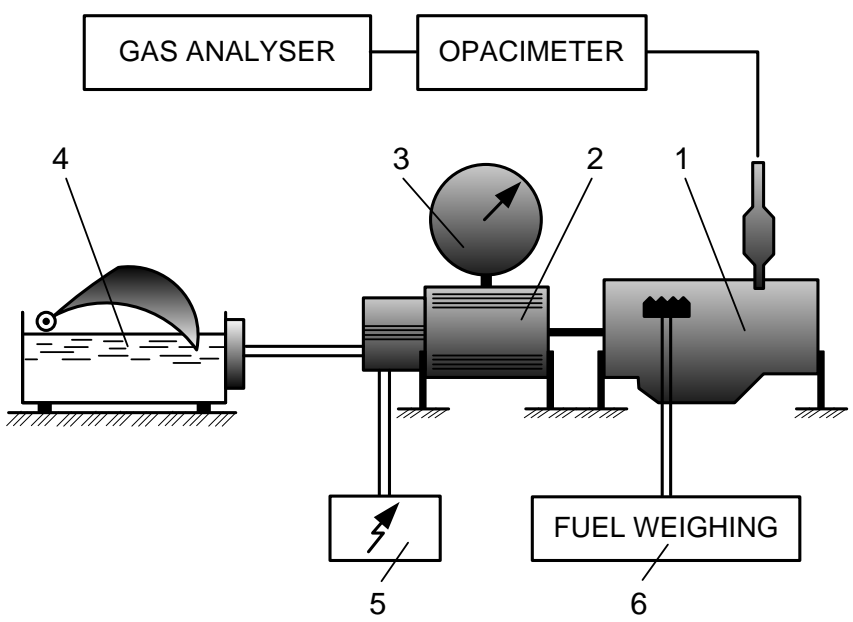

Figure 2. Engine test stand chart: 1 - engine D144; 2 generator; 3 -scales; 4 - liquid rheostat; 5 - panel; 6 fuel weighing device; 7 - gas emission measurement devices

Air-cooled engine D144 capacity is $37 \mathrm{~kW}$, displacement is $4.15 \mathrm{l}$, cylinder diameter / stroke $105 / 120 \mathrm{~mm}$, compression ratio - 16.5. Fuel pumps ND 21/4 are monocylindrical.

Three-flow blowguns 6T2 were checked on a stand $\mathrm{KI}-16301^{\mathrm{a}}$ (stand was produced in the Institute of Agricultural Engineering, Raudondvaris, Lithuania) and adjusted $17.5 \pm 0.5 \mathrm{MPa}$ for the initial raise pressure of the needle.

Before testing, one liter of oil M-10G2K was added to the engine crankcase. Fuel pump was adjusted to geometric fuel start-up of $25 \pm 1^{0}$ to the upper endpoint.

Engine torque was measured on a stand with accuracy $5 \%$. Rotation frequency was measured by a digital tachometer TESA (TESA Group, Bergdietikon, Switzerland,) with accuracy 1\%. Engine state during tests was controlled measuring oil pressure with the accuracy $20 \mathrm{kPa}$ and temperature by logometer $\check{\mathrm{S}}$ 69000 with TSM resistance thermometer (TSM Corporation, Bartlett, USA) with accuracy $5^{\circ} \mathrm{C}$.
Effective torque was measured with accuracy 5\%. The force measuring mechanism was tested by objection lever. Fuel consumption was set by weighing scales with $5 \mathrm{~g}$ accuracy, and time was measured by a stopwatch SDS with 0.2 sec accuracy.

Exhaust smoke was set with accuracy $3 \%$ by TECNOTEST-490 opacimeter (TECNOTEST, Parma, Italy). Exhaust emission composition was measured by gas analyzer TECNOTEST-481 (TECNOTEST, Parma, Italy). Engine characteristics were tested at a constant rotation frequency $\mathrm{n}=1600 \mathrm{~min}^{-1}$. The mode is selected by adjusting fuel supply lever and changing engine load. Before starting measurements, having changed engine running mode, the engine was allowed to operate for $5 \mathrm{~min}$. When changing the type of fuel, used fuel was released from fuel filters and supply tubes, also cleaning filter elements were replaced. Supply system was filled with fuel by manual pump, and air was removed. Fuel remaining from previous operation in high-pressure pump, pipes and sprinklers were consumed by engine operation and determining its operation mode.

Engine is started with stand assistance; it is warmed up to operating temperature, and the required operating mode is set. It is allowed to work in the set mode for 5-7 minutes. After that, time during which 100 or $200 \mathrm{~g}$ of fuel is burned was fixed (depending on engine load). At the same time, exhaust emissions and smoke composition was measured by gas analyser TECNOTEST-481. Smoke opacity determined with $\pm 3 \%$ accuracy.

The technical-economical calculations of the cogeneration power plant were carried out by comparing the cogeneration power plant indicators using commercial mineral diesel and in the domestic conditions obtained rapeseed oil. Technological comparative calculations were carried out by the methodology approved and used in the Aleksandras Stulginskis University [21, 22].

\section{Results and discussion}

Based on the results of experimental studies of the test engine performance and an analysis of information sources, for practical applications has been selected high power $(1050 \mathrm{~kW})$ diesel engine. Calculated analytically energy flow distribution in cogeneration power plant with this selected diesel engine is presented in figure 3. 


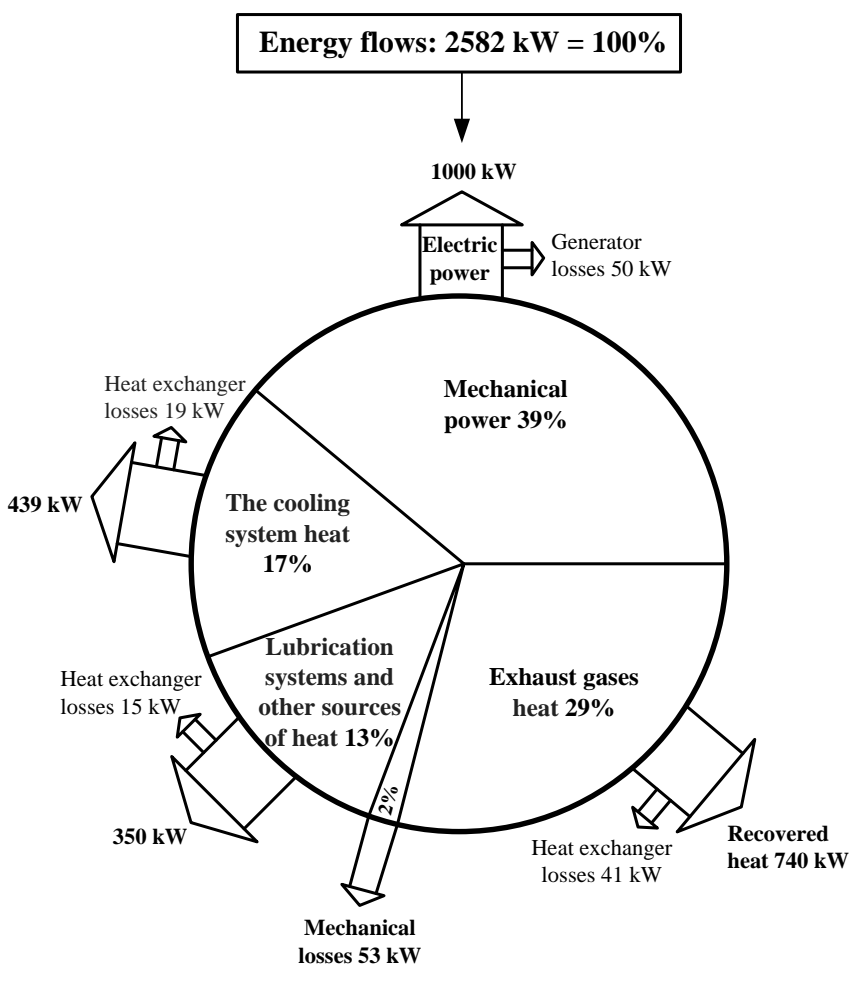

Figure 3. Distribution of energy flows in cogeneration power plant
It was determined that mechanical power of the engine is more than twice smaller than the power of heating module. Thus, total energetic efficiency is highly dependent on the fact how effectively heat obtained by cogeneration is used. Within MaySeptember, it is almost impossible to achieve efficient operating in energy system of one block of the power plant. Compared to winter months, heat demand makes only 10-20\% [13]. Meanwhile, demand of electricity changes insignificantly. However, exploitation of several energetic blocks of smaller power and switching them on with the first needs of heat energy is not the most optimal variant. Firstly, total efficiency of such power plant reduces, and investment costs increase. The system gets rather complicated to manage. It is possible for cogeneration power plants to stabilise operating mode by directing energy obtained from heat exchangers and recuperators to cooling and conditioning systems [9, 10].

Experimentally determined and calculated hourly $\left(B_{d}\right)$ and relative $\left(b_{e}\right)$ rates of fuel consumption, depending on the engine brake power $\left(\mathrm{P}_{\mathrm{e}}\right)$ working with mineral diesel (MD), rapeseed oil methyl ester (RME) and rape seed oil (oil), data is presented in Table 3.

Table 3. Fuel consumption with the engine running with mineral diesel, RME and rapeseed oil

\begin{tabular}{|c|c|c|c|c|}
\hline Fuel type & $\begin{array}{l}\text { Engine rotation } \\
\text { frequency } \\
\text { n, min }{ }^{-1}\end{array}$ & $\begin{array}{l}\text { Engine brake } \\
\text { power } \mathrm{P}_{\mathrm{e}}, \mathrm{kW}\end{array}$ & $\begin{array}{c}\text { Hourly rate } \\
\text { of fuel } \\
\text { consumption } \\
\mathrm{B}_{\mathrm{d}}, \mathrm{kg} / \mathrm{h} \\
\end{array}$ & $\begin{array}{c}\text { Relative rate of } \\
\text { fuel consumption } \\
b_{e}, g / k W h\end{array}$ \\
\hline \multirow{6}{*}{ Mineral diesel (MD) } & 800 & - & 0.80 & - \\
\hline & 1000 & 12 & 3.46 & 432 \\
\hline & 1600 & 20 & 4.71 & 333 \\
\hline & 1600 & 26 & 5.40 & 255 \\
\hline & 1600 & 32 & 7.35 & 198 \\
\hline & 1600 & 37 & 8.00 & 232 \\
\hline \multirow{6}{*}{$\begin{array}{l}\text { Rapeseed oil methyl ester } \\
\text { (RME) }\end{array}$} & 800 & - & 0.80 & - \\
\hline & 1000 & 12 & 3.60 & 518 \\
\hline & 1600 & 20 & 5.22 & 376 \\
\hline & 1600 & 26 & 6.01 & 308 \\
\hline & 1600 & 32 & 8.01 & 225 \\
\hline & 1600 & 37 & 8.75 & 263 \\
\hline \multirow{5}{*}{ Rape seed oil (oil) } & 800 & - & 0.75 & - \\
\hline & 1000 & 12 & 3.51 & 548 \\
\hline & 1600 & 20 & 5.11 & 413 \\
\hline & 1600 & 26 & 6.06 & 315 \\
\hline & 1600 & 32 & 8.20 & 230 \\
\hline
\end{tabular}

As these data show, comparative fuel consumption is the lowest when the engine works under the nominal load. Using mineral diesel, it is 198 $\mathrm{g} / \mathrm{kWh}$; using rape methyl ester, it is $225 \mathrm{~g} / \mathrm{kWh}$, and using vegetable oil, it is $230 \mathrm{~g} / \mathrm{kWh}$. 
Exhaust emissions of $\mathrm{CO}$ and $\mathrm{NO}_{\mathrm{x}}$ numerical modes are presented in Table 4. values depending on the diesel engine operating

Table 4. Exhaust emissions of the engine operating with RME, mineral diesel and rapeseed oil

\begin{tabular}{|c|c|c|c|c|}
\hline Fuel type & $\begin{array}{l}\text { Engine rotation } \\
\text { frequency } \\
\text { n, min } \text { mi }^{-1}\end{array}$ & $\begin{array}{c}\text { Engine brake } \\
\text { power } \\
\mathrm{P}_{\mathrm{e}}, \mathrm{kW} \\
\end{array}$ & $\begin{array}{c}\text { Exhaust emissions of } \\
\mathrm{CO}, \mathrm{mg} / \mathrm{m}^{3}\end{array}$ & $\begin{array}{c}\text { Exhaust emissions of } \\
\qquad \mathrm{NO}_{\mathrm{x}}, \mathrm{mg} / \mathrm{m}^{3}\end{array}$ \\
\hline \multirow{6}{*}{ Mineral diesel (MD) } & 800 & - & 266.26 & 170.71 \\
\hline & 1000 & 12 & 388.68 & 139.88 \\
\hline & 1600 & 20 & 511.44 & 200.7 \\
\hline & 1600 & 26 & 716.89 & 314.1 \\
\hline & 1600 & 32 & 336.72 & 2018.43 \\
\hline & 1600 & 37 & 149.82 & 2432.91 \\
\hline \multirow{6}{*}{$\begin{array}{l}\text { Rapeseed oil methyl } \\
\text { ester (RME) }\end{array}$} & 800 & - & 301.81 & 495.11 \\
\hline & 1000 & 12 & 471.46 & 214.29 \\
\hline & 1600 & 20 & 461.16 & 222.92 \\
\hline & 1600 & 26 & 429.99 & 344.96 \\
\hline & 1600 & 32 & 288.26 & 2204.49 \\
\hline & 1600 & 37 & 183.36 & 2380.37 \\
\hline \multirow{6}{*}{ Rape seed oil (oil) } & 800 & - & 200.85 & 519.18 \\
\hline & 1000 & 12 & 457.52 & 228.51 \\
\hline & 1600 & 20 & 460.96 & 251.47 \\
\hline & 1600 & 26 & 458.21 & 367.44 \\
\hline & 1600 & 32 & 292.64 & 2867.12 \\
\hline & 1600 & 37 & 177.62 & 2453.71 \\
\hline
\end{tabular}

More exact evaluation of RME and rape seed oil on the environment is assessed by calculating relative emissions when mineral diesel emissions are equal to $100 \%$. The relative amount of $\mathrm{NO}_{\mathrm{x}}$ in exhaust gases $\mathrm{l}$ operating with different fuels is given in figure 4 , and the relative amount of $\mathrm{CO}$ in exhaust gases - in figure 5.

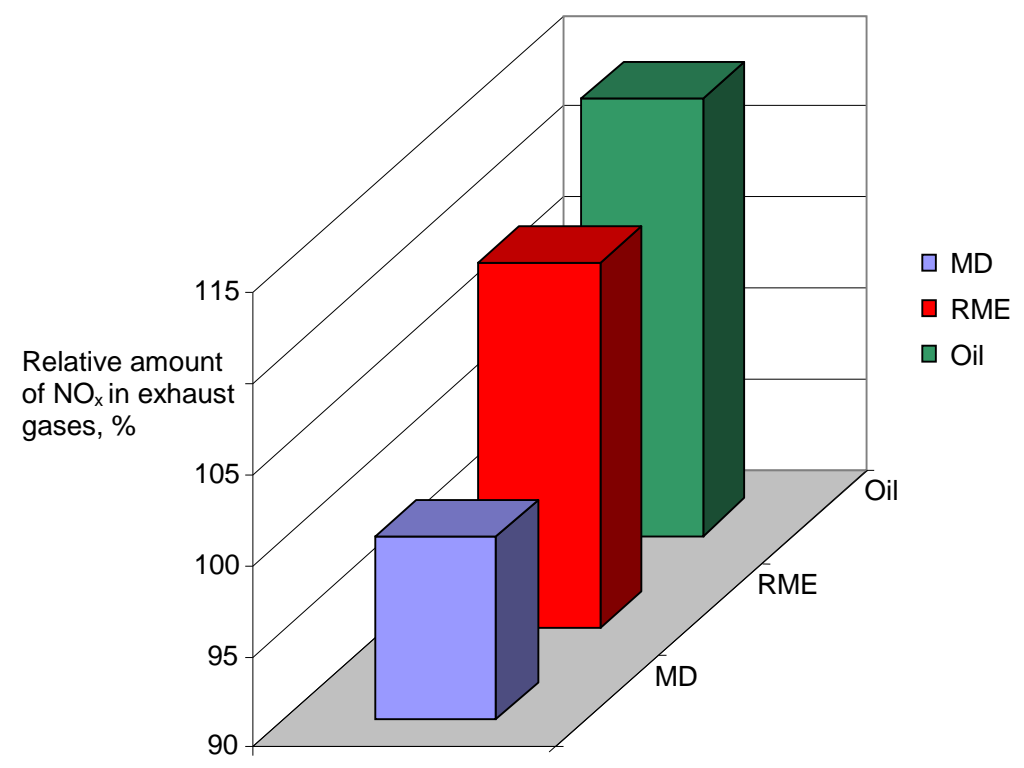

Figure 4. The relative amount of $\mathrm{NO}_{\mathrm{x}}$ gases depending on fuel type 


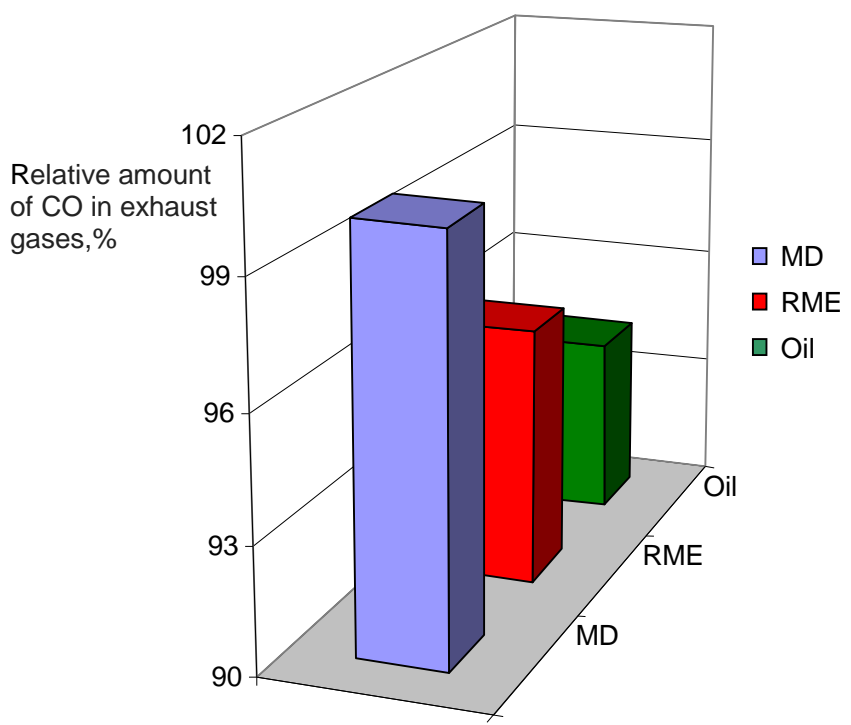

Figure 5. Relative CO emissions in exhaust gases depending on fuel type

As the received data show, replacement of mineral diesel with pure RME or rapeseed oil released into the environment increased $\mathrm{NO}_{\mathrm{x}}$ content $-10 \%$ and 13\%. Relative CO emissions in exhaust gases when operating on pure RME decrease $5.7 \%$ compared to mineral diesel, and when operating on rapeseed oil - 6.3\%. Exhaust gas relative opacity, depending on the fuel type, is presented in figure 6.

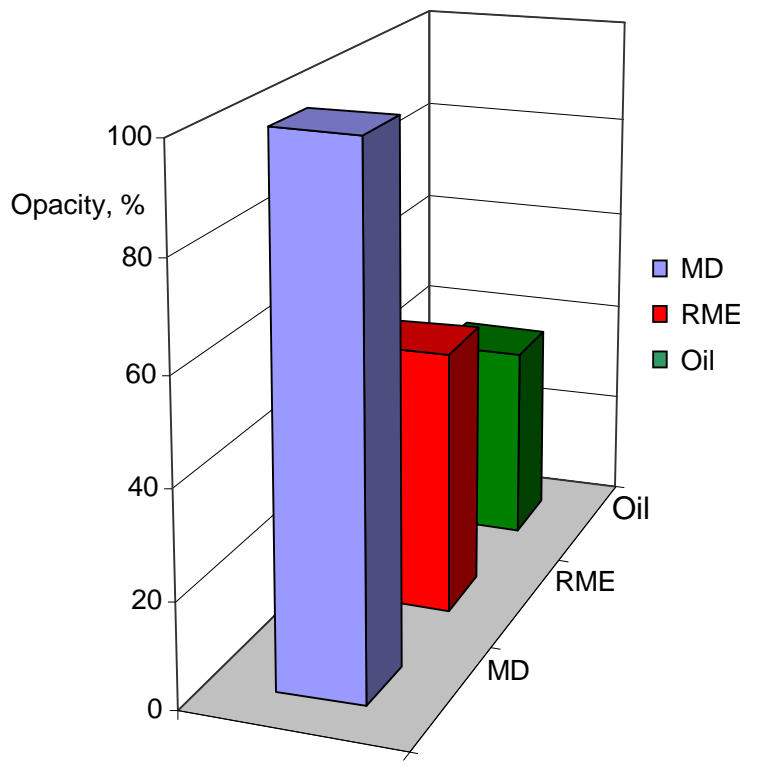

Figure 6. Relative exhaust smoke operating on various fuels

Exhaust smoke is the largest when the engine operates in medium load mode. Having replaced mineral diesel with RME, exhaust smoke reduced to $68 \%$ and if replaced with pure oil - to $72 \%$. When operating on blends of these fuels, smoke opacity decreases with increasing RME content in the blend.

Summarizing the obtained results there were concluded, that the assessment of the relative $\mathrm{NO}_{\mathrm{x}}$ and CO emissions of the gases and smoke, RME and rapeseed oil has a better impact on the environment. Compared to mineral diesel, RME and rapeseed oil lags behind only by $\mathrm{NO}_{\mathrm{x}}$ emissions exhausted from the engine to the environment. This problem can be solved by adjusting the engine or installing catalytic converters in the exhaust system.

\section{Technical-economical evaluation of cogeneration power plant using rapeseed oil fuel}

Technical-economical indices for evaluation of rapeseed oil as fuel used for evaluation of cogeneration power plant (choosing reaping with capacity of 500 tons oil per annum that is suitable for 
process rape seeds grown on a plot of 750 ha) are per year, 1500 tons of rape seed are used [21;22]. presented in Table 5. For production of 500 tons of oil

Table 5. Costs of rapeseed oil production [21,22]

\begin{tabular}{|c|c|c|c|}
\hline Name of materials and expenses & Quantity & $\begin{array}{c}\text { Price EUR/ } \\
\text { measure unit }\end{array}$ & $\begin{array}{c}\text { Amount of EUR } \\
\text { thousand/year }\end{array}$ \\
\hline Rape seed, $\mathrm{t}$ & 1500 & 290 & 434.4 \\
\hline Electric power, MWh & 95 & 124 & 11.78 \\
\hline Amortization payments (7\%) & & 52132 & 3.65 \\
\hline $\begin{array}{c}\text { Deductions for repairs: } \\
\text { - oil pressure press (5\%) } \\
\text { - other equipment (2\%) }\end{array}$ & & 12164 & 0.6 \\
\hline Salary (with the enrichment charge), worker & 1 & 39968 & 0.8 \\
\hline Seed processing and storage, t & 1500 & 348 & 2.1 \\
\hline Transport & & 15 & 1.7 \\
\hline $\begin{array}{c}\text { Common production costs, marketing and other } \\
\text { costs }\end{array}$ & & & 6.14 \\
\hline Total: & & & 482.9 \\
\hline
\end{tabular}

Oil prime-cost is calculated as the difference between costs and revenues, i.e. after selling oilcake to cattle farmers. Table 6 presents prime-costs of oil as fuel taking into consideration income for cost of income for the cake [22].

Table 6. Revenue for the cake and oil prime-cost [22]

\begin{tabular}{|l|c|c|c|c|}
\hline $\begin{array}{c}\text { Name of } \\
\text { product }\end{array}$ & Unit & $\begin{array}{c}\text { Quantity, } \\
\mathrm{t}\end{array}$ & $\begin{array}{c}\text { Price, } \\
\text { EUR/t }\end{array}$ & $\begin{array}{c}\text { Amount, } \\
\text { thousand } \\
\text { EUR/year }\end{array}$ \\
\hline Cake & $\mathrm{t}$ & 1000 & 139 & 139 \\
\hline $\begin{array}{l}\text { Oil (prime- } \\
\text { cost) }\end{array}$ & $\mathrm{t}$ & 500 & & 344 \\
\hline
\end{tabular}

Prime-cost of $1 \mathrm{~kg}$ of oil -0.69 EUR

Price of 1 litre of oil - EUR $0.69 \times 0.87=0.60$ EUR

Estimated oil price of $0.60 \mathrm{EUR} / \mathrm{l}$ is smaller than the price of commercial mineral diesel (1.30 EUR/l) and is equal to the price of diesel fuel for farmers.

The price of the selected $340 \mathrm{~kW}$ electric power cogeneration power plant block is EUR 130 thousand. Considering the study results stating that fuel consumption is $14 \%$ higher if using rapeseed oil than using mineral diesel in diesel engines, fuel consumption of the power plant is $65 \mathrm{l} / \mathrm{h}$. Economic benefits of such power plant working on a green oil are presented in Table 7 [21;22].

Table 7. Economic indicators of cogeneration power plant of $340 \mathrm{~kW}[21,22]$

\begin{tabular}{|l|c|}
\hline \multicolumn{1}{|c|}{ Parameters } & Data \\
\hline Power plant cost, EUR & 130329 \\
\hline Building cost, EUR & 8689 \\
\hline Fuel price, EUR/liter & 0.6 \\
\hline Working time, h/year & 6000 \\
\hline Amortization payment, EUR: & 19550 \\
for equipment & 174 \\
\hline for building & 6951 \\
\hline Costs of service, EUR/year & 232681 \\
\hline Fuel price, EUR/year & 5792 \\
\hline other costs, EUR/year & 265147 \\
\hline \multicolumn{1}{|c|}{ Total costs, EUR/year } & 0.13 \\
\hline Price of realized electricity, EUR/kWh & 2040000 \\
\hline Produced electricity, kWh/year & 265813 \\
\hline Income from electricity, EUR/year & 2460000 \\
\hline Produced heat energy, kWh/year & 0.03 \\
\hline Heat energy prime-cost, EUR/kWh & \\
\hline
\end{tabular}


Having evaluated quantity of electric and heat energy produced in cogeneration power plants, its efficiency would make up to 79095 EUR/year. The payback period of such power plants would reach 1.76 years on the average, it is about twice less than payback using mineral diesel.

\section{Conclusions}

1. The performed literature analysis showed that diesel engines using liquid or gas fuels are the most perspective for small and medium power cogeneration power plants in Lithuania.

2. Ensuring independence of producers of dispersed energy from fuel suppliers and reduction of dangerous emission to the environment, it is purposeful to use personal production rapeseed oil and its blends with mineral diesel as fuel in cogeneration power plants.

3. It has been determined that using biofuels in cogeneration power plant with diesel engine, mechanical power is twice smaller than the received heat in module power.

4. Having performed environmental evaluation of biofuel it was determined that the least emission of $\mathrm{CO}$ and solid particles to the environment is achieved if using rapeseed oil as fuel. However, during its burning, higher amount of $\mathrm{NO}_{\mathrm{x}}$ is emitted than using mineral diesel or rapeseed ester methyl.

5. If compared options of using rapeseed oil as fuel in cogeneration power plants, after evaluation of quantities electric and heat energy produced in cogeneration power plants, it may be stated that its efficiency would make up to 79095 EUR/year, and the payback period of such power plants is about twice less than payback using mineral diesel. This is explained by lower rapeseed production costs compared to mineral diesel costs.

\section{References}

[1] Macinauskas, K., Korsakienė, I., Tumosa, A., 2008. Cogeneration "termofication" and microturbines. Energetika, 54 (2), 70-78 (In Lithuanian).

[2] Directive 2004/8/EC of the European Parliament and of the Council of 11 February 2004 on the promotion of cogeneration based on a uself heat demand in the internal energy markt and amending directive 92/42/EEC.
[3] Alonso-Pippo, W., Luengo, C. A., Fonseca, F. F., Garzone, P., Conacchia, G., 2009. Energy recovery from sugar cane biomass residues : challenges and opportunities of bio-oil production in the light of second generation biofuels. J Renew Sustain Energy. 2009; 1:063102, 1-15.

[4] Hobson, P., 2009. Torrefaction and gasification forhighefficiency second-generation biofuel production. In : Proceedings of the Australian sočiety of sugarcane technologists. 31, 389-399.

[5] Olivério, J. L., Ferreira, F. M., 2010. Cogeneration a new source of income for sugar and ethanol mills or bioelectricity - a new business. In : Proceedings of international society of sugar cane technologists, 13.

[6] Žukauskas, G., Zinkevičius, F., 2007. Low-power cogeneration plants in Lithuania. Pover plant, 53 (2), 43-47 (In Lithuanian).

[7] Bini, R., Duvia, A., Schwarz, A., 2004. Operational Results ot the First Biomass CHP Plant in Italy based on Organic Rankine Cycle Turbogenerator and Overview of a Number of Plants in Operation in Europe Since 1998. Proceeding of Second World Biomass Conference, Rom.

[8] Duvia, A., Guzikowski, J., 2006. Innovation project in Ostrow Wielkopolski. Clean Energy, 11, 24-25 (In Polish).

[9] Teislev, B., 2004. Wood_Chips Updraft Gasifier Based Combined Heat and Power. Proccedings of Second World Biomass Conference, Rom.

[10] Zaaporowski, B., 2009. Low-power CHP plant burned by biomass. Clean energy, 11, 38-39 (In Polish).

[11] Bolhar-Nordenkampf, M., Proll, T., Aichering, C., Hofbauer, H., 2004. Techno Economical Assessment of Combined Heat and Power Production from Biomass. Proccedings of Second World Biomass Conference, Rom.

[12] Persson, M., 203. Evalution of upgrading techniques for biogas. Report SGC, „,Swedish Gas Center", 142.

[13] Berglund, M., 2006. Biogas production from a systems analytical perspective. Research papers. Lund university, Lund.

[14] Raslavičius, L., Kučinskas, V., Jasinskas, A., 2013. The prospects of energy forestry and agroresidues in the Lithuania's domestic energy supply. Renewable and Sustainable Energy Reviews, 22, 419-431.

[15] Jasinskas, A., Šateikis, I., 2009. Evaluation of Plant Biomass Potential and Technologies of Biomass Preparation and Utilization for Energy Purposes 
in Lithuania. Rural development 2009: the fourth international scientific conference, 15-17 October, 2009, Akademija, Kaunas region, Lithuania : proceedings, 4 (2), 327-332.

[16] Kraujalis, A., Nakčiūnas, M., 2005. Research of biofuel mixtures costs and impact to the tractor parts in the operstional - dynamic conditions. 11-th Scientific Conference "Man and Nature Safety". 2-4 June 2005, LUA, Kaunas, 39-41 (In Lithuanian).

[17] Kraujalis, A., Liubarskis, V., Raslavičius, L., 2005. Biodiesel and their blends with mineral diesel consumption analysis fuelling tractors of small and average capacity. Journal of research and applications in agricultural engineering, 50 (1), 45-48.

[18] Liubarskis, V., Raslavičius, L., 2003. Vista of fueling diesel engine with fuel blends. New methods, means and technologies for applications of agricultural products: proceedings of the international conference. Kaunas reg., Raudondvaris, 18-19 September 2003, 39-42.

[19] Nakčiūnas, M., 2005. Research of possibilities of using mineral diesel and rapeseed oil blends for fuel. New technological processes and investigation methods for agricultural engineering: proceedings of the 10-th International Conference. Kaunas reg., Raudondvaris, 8-9 September 2005, 263-268.

[20] Poinsot, T., Veynante, D., 2005. Theoretical and numerical combustion. 2nd Edition. Flourtown, PA: R. T. Edwards, Inc., 540.

[21] Mechanized agricultural service fees. Vilnius: LAEI, 2013. D. 3.: Works of harvesting. 2013, 64 (In Lithuanian). (http://www.laei.lt).

[22] Mechanized agricultural service fees. Vilnius: LAEI, 2011. D.2.: Works of crop supervision and harvesting. 2011, 78 (In Lithuanian). (http://www.laei.lt) 